Chirurgia (2017) 112: 443-448

No. 4, July - August

Copyright@ Celsius

http://dx.doi.org/10.21614/chirurgia.112.4.443

\title{
Elucidation of a Conserved Proteomic Pattern of Breast Cancer Tissue and Metastatic Axillary Lymph Node
}

\author{
Gurler Akpinar', Turgay Simsek², Ata Guler², Murat Kasapp', Nuh Zafer Canturk ${ }^{2,3}$ \\ ${ }^{1}$ Kocaeli University Medical School Department of Medical Biology and Genetics, DEKART Proteomics Laboratory, Kocaeli, Turkey \\ ${ }^{2}$ Kocaeli University Medical School Department of General Surgery, Kocaeli, Turkey \\ ${ }^{3}$ Vice President of Turkish Senology Academia (SENATURK), Turkey
}

Corresponding author: Nuh Zafer Cantürk, MD Professor in Surgery and Surgical Oncology, Medical Director Kocaeli Universitesi Hastanesi Genel Cerrahi Anabilim Dall, Umuttepe Kocaeli, Turkey E-mail: canturkz@yahoo.com

\section{Rezumat}

Elucidarea unui model proteomic conservat al cancerului de sân și al ganglionilor limfatici axilari metastatici

Obiectiv: Cancerul de sân este unul dintre cele mai devastatoare tipuri de cancer care afectează femeile. Pentru luarea deciziilor critice cu privire la soarta țesutului mamar canceros, este necesară evaluarea implicării ganglionilor limfatici axilari (ALN). Cu toate acestea, o astfel de implicare ALN este dificil de prezis fără intervenția chirurgicală. Prin urmare, un test uşor de predicție care utilizează markeri de proteine poate fi o abordare dorită. În acest studiu, am efectuat o analiză completă a proteinomei pentru a descoperi modelul de exprimare a proteinelor legate de tumori în cancerul de sân primar.

Metode şi Materiale: Proteinele au fost extrase din țesuturile tumorale şi au fost supuse unei electroforeze în gel de poliacrilamidă în două dimensiuni (2D). Imaginile de gel rezultate au fost utilizate pentru compararea spoturilor inter-gel utilizând software-ul PDQuest Advance. Modelele obținute au fost utilizate pentru diferentierea tipurilor tumorale invazive de la cele neinvazive.

Rezultate: 24 de pete de proteine conservate ale căror intensități au fost moderat reglementate înalt pe geluri. Aceste pete de proteine au fost folosite pentru a crea un model conservat $2 \mathrm{D}$ care acoperă un interval de $\mathrm{pH}$ de la 4 la 8.

Concluzie: Punctele proteice care generează un model conservat între cancerul de sân primar şi ganglionul limfatic axilar au indicat că o abordare proteomică robustă şi foarte fiabilă, de exemplu $2 \mathrm{DE}$, poate fi utilizată pentru a diferenția forme metastatice de cancer de sân de la cele nemetastatice. 
Cuvinte cheie: cancer de sân, axilar, ganglion limfatic, 2D, proteomică

\begin{abstract}
Objective: Breast cancer is one of the most devastating cancer types affecting women. For critical decision making regarding the fate of cancerous breast tissue, the assessment of axillary lymph node (ALN) involvement is required. However, such ALN involvement is difficult to predict without surgical intervention. Therefore, an easy predictive test using protein markers may be a desirable approach. In this study, we performed a whole proteome analysis to reveal the presence of a putative biomarker panel using primary breast tumor tissue.

Materials and Methods: Proteins were extracted from tumor tissues and were subjected to two dimensional (2D) gel electrophoresis. The resulting gel images were used for inter-gel spot comparisons using PDQuest Advance software. The paterns thus obtained were used for differentiating invasive tumor types from non-invasive ones.

Results: The analysis of $2 \mathrm{D}$ gel images revealed the presence of 24 conserved protein spots whose intensities were moderately regulated high on the gels. Those protein spots were used to create a conserved 2D pattern spanning a $\mathrm{pH}$ range of 4 to 8 .

Conclusion: Protein spots generating a preserved model among pattern between primary breast cancer and its axillary lymph node indicated that a robust and highly reliable proteomic approach, e.g., 2DE may be used to differentiate metastatic forms of breast cancer from non-metastatic ones.
\end{abstract}

Key words: breast cancer, axillary, lymph node, 2D, proteomics

\section{Introduction}

Breast cancer is the most commonly observed cause of cancer-related deaths among the women both in our country and around the world (1). The metastasis of the disease to other tissues primarily occurs via the lymphatic system (2). Cancer cells spread to the lymph nodes may then spread to distantly located organs e.g., lungs, liver and bones $(3,4)$. Although there are various indicators of the spread of cancer cells, the lymph node metastasis is probably the most distinguished indicator and can be used to determine the stages of cancer, can give information about prognosis and be helpful in decision-making process about the possible therapies that is applied to the patients $(5,6)$.

It has long been known that patients with Auxiliary Lymph Node (ALN) metastasis have worsened prognosis than the patients who do not have ALN. That is why the presence of ALN is still the most critical parameter in clinical decision making process. In more than several studies, it was demonstrated that ALN negative cases display better prognosis than ALN positive cases $(8,9)$. These studies demonstrated that the number of metastatic lymph nodes is the determinant parameter for application of the adjuvant therapy $(7,10)$. Despite the presence of these evidential data, there are ALN negative cases in which metastasis was present and ALN positive cases in which ten-year of survival without metastasis was observed $(11,12)$. These observations led us question the reliability of ALN as the sole determinant of metastatic spread. Sentinel lymph node biopsy (SLNB) is considered to be an alternative to ALN dissection made for determination of ALN metastasis because ALN dissections are among the main reasons of morbidity. Yet, the observation of lymph node edema after SLNB raised the need for a less invasive method for evaluation of Auxiliary lymph nodes (13).

In this study, we used 2D gel electrophoresis 
based proteomic approach to elucidate a pattern formed that may be useful in differentiation of metastatic $\mathrm{BCs}$ from non-metastatic BCs. Although this is preliminary study, it provided clues about the use of conventional proteomic approaches in differential diagnosis of BC.

\section{Materials and Methods}

\section{Sample Preparation}

The study was conducted at Kocaeli University Medical School DEKART Proteomics Laboratory, Turkey. Informed consents, approved by the institutional ethics committee, were obtained from each patient. Patients who received radio therapy or neo-adjuvant were not included in the study. We only included patients with pathologically confirmed ALN. All patients were followed at the Department of General Surgery and the tissue samples from ten ALN patients were used in this study. Tissues were removed and immediately snap-frozen in liquid nitrogen and stored at $-80^{\circ} \mathrm{C}$ until use. The clinical and biochemical properties of the patient were summarized in Table 1.

Tissue samples were minced on ice and washed with ample amount of ice-cold phosphate buffer for three times to remove excess blood. After $10 \mathrm{~min}$ centrifugation at $4^{\circ} \mathrm{C}$ at $2000 \times g$, the excess buffer was decanted and 100 $\mu \mathrm{L}$ of TPER buffer (Pierce Inc., USA) was added over each tissue pellet. To achieve complete lysis, the tissue pellets were vigorously vortexed using a Next Advance homogenizer with $1.6 \mathrm{~mm}$ stainless steel beads at $+4^{\circ} \mathrm{C}$ in $2 \mathrm{DE}$ rehydration buffer (8M urea, $2 \mathrm{M}$ thiourea, 4\% CHAPS, $30 \mathrm{mM}$ Tris $\mathrm{pH} 8.5$, and $1 \mathrm{x}$ protease inhibitor cocktail) and the supernatant containing the soluble protein fraction was obtained by centrifugation at $20.000 \times \mathrm{g}$ for $30 \mathrm{~min}$ at $4^{\circ} \mathrm{C}$. Protein concentration was determined by using modified Lowry assay with the BSA standard (BioRad, USA). The soluble protein containing supernatants were stored in Lo-bind tubes (Eppendorf, USA) at $-80^{\circ} \mathrm{C}$ until analysis.

\section{Two-Dimensional Gel Electrophoresis (2DE-PAGE)}

For the first-dimensional separation via isoelectric focusing (IEF), $550 \mu \mathrm{g}$ from each protein sample was loaded onto immobilized $\mathrm{pH}$ gradient strips (IPG) (17 cm, $\mathrm{pH} 3-10$, linear) via active rehydration $\left(50 \mu \mathrm{A} / \mathrm{IPG}\right.$ strip, at $20^{\circ} \mathrm{C}$ for $16 \mathrm{~h}$ ). Isoelectric focusing was performed using Protean isoelectric focusing cell (BioRad, USA). The strips were run through a stepwise incremental voltage program $[250 \mathrm{~V}$ for $30 \mathrm{~min}$ (linear), $4000 \mathrm{~V}$ for $2.5 \mathrm{hr}$ (linear) and $40000 \mathrm{~V} / \mathrm{hr}$ (rapid)]. The plate temperature was maintained at $20{ }^{\circ} \mathrm{C}$. The strips were then subjected to a two-step equilibration in equilibration buffers containing $6 \mathrm{M}$ urea, $2 \% \mathrm{SDS}, 0.375 \mathrm{M}$ Tris- $\mathrm{HCl}$ $\mathrm{pH} 8.8,20 \%$ glycerol and 2\% DTT for the first step and the same buffer without DTT but with iodoacetamide $(2.5 \%)$ for the second step with 20

Table 1. Clinical findings of the patients (ER; estrogen receptor, PR; progesterone receptor)

\begin{tabular}{|c|c|c|c|c|c|c|c|c|c|c|}
\hline Patient code & Age & Stage & $\begin{array}{c}\text { Diameter of } \\
\text { the tumor }\end{array}$ & $\begin{array}{l}\text { Spread } \\
\text { to ALN }\end{array}$ & ER & PR & C-erB 2 & Grad & $\begin{array}{l}\text { Family } \\
\text { history }\end{array}$ & Localization \\
\hline SB\#1 & 55 & III & $8.5 \mathrm{~cm}$ & $2 / 19$ & + & - & - & 2 & - & Right \\
\hline $\mathrm{HG} \# 2$ & 35 & III & $5.5 \mathrm{~cm}$ & $12 / 17$ & + & + & - & 2 & - & Right \\
\hline NE\#3 & 70 & III & $2.5 \mathrm{~cm}$ & $6 / 17$ & + & + & - & 2 & - & Left \\
\hline PE\#4 & 65 & III & $2.1 \mathrm{~cm}$ & $8 / 16$ & + & - & - & 2 & - & Right \\
\hline ȘB\#5 & 59 & III & $3.0 \mathrm{~cm}$ & $4 / 13$ & + & - & + & 2 & - & Right \\
\hline HM\# 6 & 50 & II & $2.7 \mathrm{~cm}$ & $2 / 15$ & + & + & + & 2 & - & Left \\
\hline KM\#7 & 52 & II & $2.9 \mathrm{~cm}$ & $3 / 12$ & + & + & - & 2 & - & Right \\
\hline SA\#8 & 48 & II & $3.3 \mathrm{~cm}$ & $3 / 10$ & + & - & - & 2 & - & Left \\
\hline KD\#9 & 55 & II & $2.1 \mathrm{~cm}$ & $7 / 16$ & + & - & - & 2 & - & Right \\
\hline MM\#10 & 49 & II & $3.1 \mathrm{~cm}$ & $5 / 14$ & + & - & + & 2 & - & Left \\
\hline
\end{tabular}


min gentle shaking. Following equilibration steps, the IPG strips were rinsed with SDSPAGE running buffer and loaded directly onto $1 \mathrm{~mm}$-thick $12 \%$ in-house made SDS-polyacrylamide gels. The second dimension was accomplished by using Dodeca gel running system (BioRad, USA) to minimize gel to gel variation. Electrophoresis was carried out at $16^{\circ} \mathrm{C}$ at $45 \mathrm{~mA} /$ gel until the front dye reached the bottom of the gels. The gels were fixed for six hours (10\% acetic acid, 40\% methanol) and stained with SYPRO Ruby (BioRad, USA). Triplicate gels were produced for each sample.

\section{Image Analysis}

The gel images were taken with VersaDoc 4000MP (BioRad, USA) and analyzed by using PDQuest Advance 2D image analysis software (Bio Rad, USA). The quality of each spot was normalized using local regression model. Based on average spot volume ratio, spots whose relative expression levels were changed ar least 2 -fold (increase or decrese) among the compared groups were considered to be significant.

\section{Results}

As listed in Table 1, female cancer patients who are at stages 5-3a and 1-2b) were accepted to this study. All cases were determined to be grade II and hormone receptor positive in their histopathological examinations. Except case II, all cases were in their postmenopausal stages. Tissue samples and lymph nodes were used to prepare protein extracts and the protein extracts were used to produce wellresolved high resolution $2 \mathrm{D}$ gels. Automated analysis of the stained $2 \mathrm{D}$ gels revealed the presence of $750 \pm 50$ protein spots. However, visual inspection and manual editing of the gels revealed that some of the protein spots detected by automated spot analysis tool were ambiguous and could not be matched even within the groups (Fig. $1 A$ and B). To overcome this problem, master gels were created for each group by matching the protein spots that were present in each member of the groups. The master gels were then used to perform inter-group comparisons (Fig. 1C). Conserved spots were determined between the groups and these spots were used to generate a conserved spot profile. There were 24 conserved spots whose intensities were moderately high on the gels. They were consisted of mostly high molecular weight proteins spanning a $\mathrm{pH}$ range of 4 to 8.

\section{Discussion}

Stages of tumor have been determined by the help of physical examination, biopsy and the use of various imaging technologies. Determination of the type of therapy that will be used for treatment is highly important for the prognosis of the disease. Cells detach from some breast tumor tissues may initially indwell into the axillary lymph nodes (14). On the other hand, some other breast tumor cells do not prefer to settle into to the lymph nodes before metastasize. The reason behind this interesting phenomenon is not known. In this study, we wished to test if we can predict ALN metastasis in breast cancer patients at a preoperative stage by performing comparative proteome analysis. There is evidence suggesting that the molecular events dictating distant organ metastasis are somewhat different then ALN metastasis (13). In a study using microarray technology, researchers demonstrated that gene expression profiles of cells from primary cancer tissues and ALNs share high similarities (13). However, other studies demonstrated otherwise claiming that metastasized cells in the ALNs display major differences than their primary look-alikes at the molecular level (15-18).

There are studies investigated breast tumor tissues and their ALNs to which tumor was metastasized. Those studies mainly demonstrated the similarities between the tumor tissues and the ALNs using histopathological examinations. The phenotypic similarities revealed in these studies were also confirmed in transcriptomic studies $(15,19-21)$. On the other hand, studies focused on chromosomal abnormalities among the primary breast tumor tissues and their respective ALNs showed some 


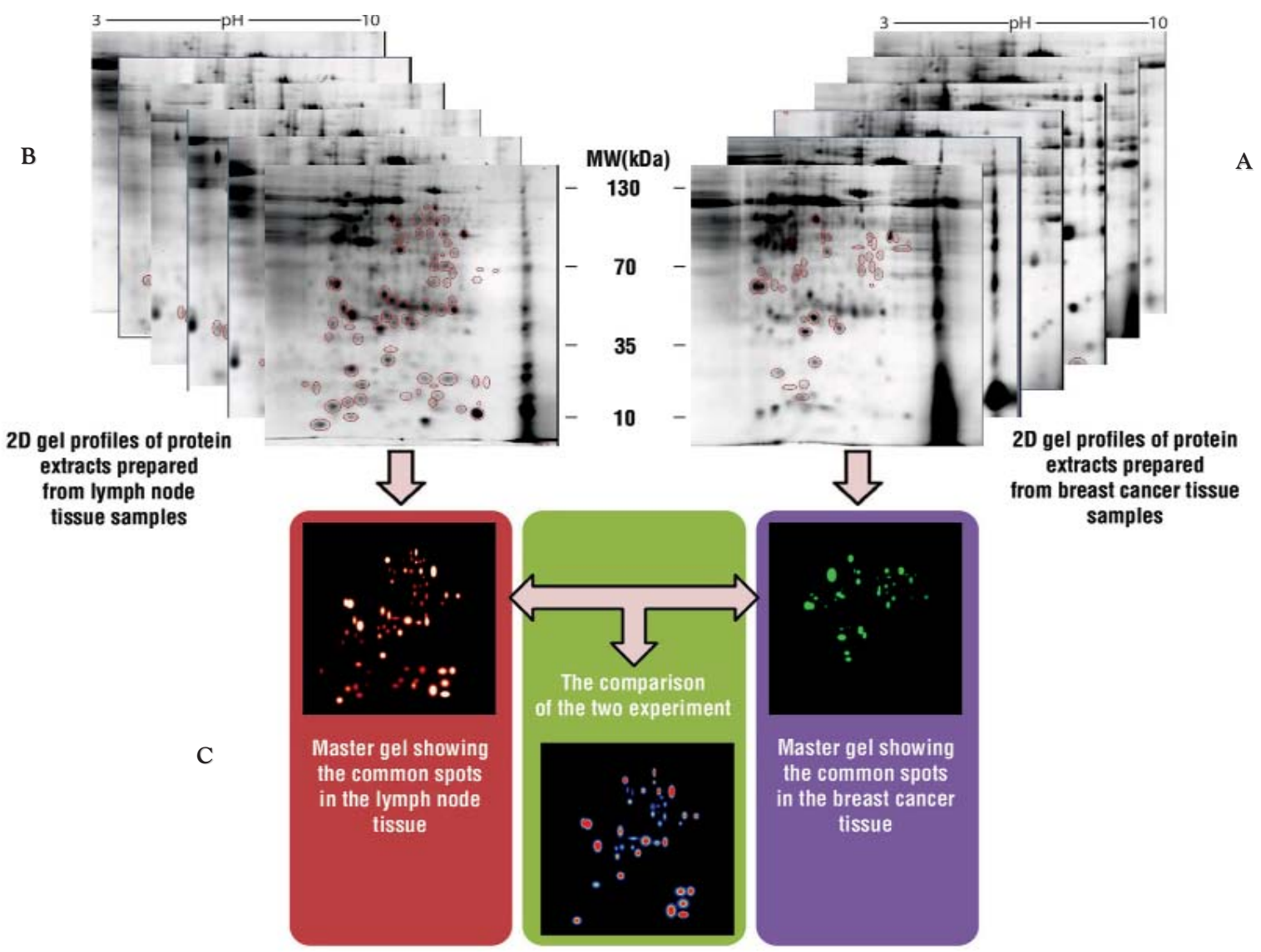

Figure 1. 2D gel analysis protein extracts from breast cancer (A) and ALN (B) tissue samples. The twenty four spots (C), that obtained from comparison of the master gels, may help explain the mechanism behind the spread of breast cancer to the lymph node

noteworthy differences $(13,22)$. In overall, a consensus cannot be reached among the studies regarding the similarities and the differences between the primary tumor tissues and their respective ALNs.

An conventional approach was utilized by Lee et al. to provide evidence at the molecular level for differentiation of primary tumor tissues from their respective ALNs to which tumor cells were metastasized. The researchers used 2D gel electrophoresis to evaluate tumor samples at different stages (NO, N1, N2). They detected 12 down-regulated and an upregulated protein spots. Subsequent LCMS/MS analysis to identify those proteins indicated that calretuculin and tropomyocine alpha were regulated in all studied tumor samples (NO, N1 and N2) in comparison to the healthy controls. In addition, the researchers proposed several potential biomarkers that may be useful for differentiation of the cancer stages. Those biomarker candidates included Hsp70 for NO, 80kDa protein $\mathrm{H}$ precursor and protein disulfide isomerase (PDI) for $\mathrm{N} 1$ and $78 \mathrm{kDA}$ glucose regulated protein for N2 (23).

In this study, to differentiate primary tumors that metastasize to ALN from the primary tumors that do not metastasize to ALN, we used a 2D based approach. We hypothesized that elucidating a proteome profile between the tumor tissues and their respective ALNs should help elucidation of proteins involving to the process of metastatic transition. We also predicted that the changes observed in the levels of these proteins might also indicate thei level of their involvement to metastasis. The assumption was also made that the spots that could not be matched among the tumor samples 
and ALN samples or between the tumor samples and their respective ALNs might originate from individual sample complexities that are commonly observed when human samples are used (24). The inner and inter group spot matching efforts revealed the presence of 24 protein spots. These 24 all-matching spots displayed a unique proteome pattern spanning a $\mathrm{pH}$ range of 4 to 8 between the molecular weight ranges of 40000 to $120000 \mathrm{Da}$. These spots are needed to be identified to obtain further clues about their roles in induction of metastasis from primary tumor tissue to nearby lymph nodes. The changes in abundance of these proteins may reflect their contribution to the rate of metastatic process.

\section{Conclusion}

In conclusion, this study placed an emphasis on the all-matching protein spots between primary tumor tissues and their respective ALNs and provided a proposition that a $2 \mathrm{D}$ gel electrophoresis pattern between $\mathrm{pH}$ ranges of 4 to 8 may be useful for predicting the metastatic process. Although initial, the results presented here demonstrated by using a multivariate approach in which evolving patterns involving more than several proteins might be used for differentiation of invasive tumor types from non-invasive ones.

\section{Acknowledgements}

This research was partly supported by grants from Kocaeli University Scientific Research Unit under the grant numbers of 2012/018.

\section{Note}

Part of this study was previously published in the "The Journal of Breast Health" (2013; 9: 64-8).

\section{References}

1. Özmen V. Breast cancer in the world and Turkey. J of Breast Health. 2008:4:7-12.

2. Cunnick GH, Jiang WG, Douglas-Jones T, Watkins G, Gomez KF, Morgan MJ, et al. Lymphangiogenesis and lymph node metastasis in breast cancer. Mol Cancer. 2008;7:23. doi: 10.1186/1476-4598-7-23.

3. Kohn EC, Liotta LA. Molecular insights into cancer invasion: strategies for prevention and intervention. Cancer Res. 1995;55(9): 1856-62.
4. Alitalo A, Detmar M. Interaction of tumor cells and lymphatic vessels in cancer progression. Oncogene. 2012;31(42):4499-508. doi: 10.1038/onc.2011.602. Epub 2011 Dec 19.

5. Nemoto T, Natarajan N, Bedwani R, Vana J, Murphy GP. Breast cancer in the medial half. Results of 1978 National Survey of the American College of Surgeons. Cancer. 1983;51(8):1333-8.

6. Rakha EA, Morgan D, Macmillan D. The prognostic significance of early stage lymph node positivity in operable invasive breast carcinoma: number or stage. J Clin Pathol. 2012;65(7):624-30. doi: 10.1136/jclinpath-2012-200755. Epub 2012 Apr 20.

7. Dent DM. Axillary lymphadenectomy for breast cancer. Paradigm shifts and pragmatic surgeons. Arch Surg. 1996;131(11):1125-7.

8. Mirza A N, Mirza NQ, Vlastos G, Singletary SE. Prognostic factors in node-negative breast cancer: a review of studies with sample size more than 200 and follow-up more than 5 years. Ann Surg. 2002;235(1):10-26.

9. Rack B, Janni W, Gerber B, Strobl B, Schindlbeck C, Klanner E, et al. Patients with recurrent breast cancer: does the primary axillary lymph node status predict more aggressive tumor progression? Breast Cancer Res Treat. 2003;82(2):83-92.

10. Woodward WA, Vinh-Hung V, Ueno NT, Cheng YC, Royce M, Tai P, et al. Prognostic value of nodal ratios in node-positive breast cancer. J Clin Oncol. 2006;24(18):2910-6.

11. Rosen PR, Groshen S, Saigo P E, Kinne DW, Hellman S. A longterm follow-up study of survival in stage I (T1NOMO) and stage II (T1N1M0) breast carcinoma. J Clin Oncol. 1989:7(3):355-66.

12. Hellman S. Karnofsky Memorial Lecture. Natural history of small breast cancers. J Clin Oncol. 1994;12(10):2229-34.

13. Weigelt B, Wessels LF, Bosma AJ, Glas AM, Nuyten DS, He YD, et al. No common denominator for breast cancer lymph node metastasis. Br J Cancer. 2005;93(8):924-32.

14. Stacker SA, Achen MG, Jussila L, Baldwin ME, Alitalo K. Lymphangiogenesis and cancer metastasis. Nat Rev Cancer. 2002; 2(8):573-83

15. Feng Y, Sun B, Li X, Zhang L, Niu Y, Xiao C, et al. Differentially expressed genes between primary cancer and paired lymph node metastases predict clinical outcome of node-positive breast cancer patients. Breast Cancer Res Treat. 2007;103(3):319-29.

16. Suzuki M, Tarin D. Gene expression profiling of human lymph node metastases and matched primary breast carcinomas: clinical implications. Mol Oncol. 2007;1(2):172-80. doi: 10.1016/j.molonc. 2007.03.005. Epub 2007 Apr 7.

17. Vecchi M, Confalonieri S, Nuciforo P, Viganò MA, Capra M, Bianchi $\mathrm{M}$, et al. Breast cancer metastases are molecularly distinct from their primary tumors. Oncogene. 2008:27(15):2148-58.

18. Li J, Gromov P, Gromova I, Moreira JM, Timmermans-Wielenga V, Rank F, et al. Omics-based profiling of carcinoma of the breast and matched regional lymph node metastasis. Proteomics. 2008;8(2324):5038-52. doi: 10.1002/pmic.200800303.

19. Daidone MG, Silvestrini R, Valentinis B, Persici P, Mezzanotte G, Squicciarini $P$, et al. Proliferative activity of primary breast cancer and of synchronous lymph node metastases evaluated by [3H]thymidine labelling index. Cell Tissue Kinet. 1990;23(5):401-8.

20. Goodson WH, Ljung BM, Moore DH, Mayall B, Waldman FM, Chew $\mathrm{K}$, et al. Tumor labeling indices of primary breast cancers and their regional lymph node metastases. Cancer. 1993;71(12):3914-9.

21. Lähdesmäki H, Hao X, Sun B, Hu L, Yli-Harja O, Shmulevich I, et al. Distinguishing key biological pathways between primary breast cancers and their lymph node metastases by gene function-based clustering analysis. Int J Oncol. 2004;24(6):1589-96.

22. Nishizaki T, DeVries S, Chew K, Goodson WH 3rd, Ljung BM, Thor A, et al. Genetic alterations in primary breast cancers and their metastases: direct comparison using modified comparative genomic hybridization. Genes Chromosomes Cancer. 1997;19(4): 267-72.

23. Lee HH, Lim CA, Cheong YT, Singh M, Gam LH. Comparison of protein expression profiles of different stages of lymph nodes metastasis in breast cancer. Int J Biol Sci. 2012;8(3):353-62. doi: 10.7150/ijbs.3157. Epub 2012 Feb 20.

24. Kasap M, Akpinar G, Kanli A. Proteomic studies associated with Parkinson's disease. Expert Rev Proteomics. 2017;14(3):193-209. doi: 10.1080/14789450.2017.1291344. Epub 2017 Feb 15. 